\title{
Carbon stored in human settlements: the conterminous United States
}

\author{
GALINA CHURKINA*†t, DANIEL G. BROWN* and GREGORY KEOLEIAN* \\ *School of Natural Resources and Environment, University of Michigan, Ann Arbor, MI 48109, USA, †Max-Planck Institute for \\ Biogeochemistry, 07745 Jena, Germany, $\ddagger$ Leibniz Center for Agricultural Landscape Research, Müncheberg, Germany
}

\begin{abstract}
Urban areas are home to more than half of the world's people, responsible for $>70 \%$ of anthropogenic release of carbon dioxide and $76 \%$ of wood used for industrial purposes. By 2050 the proportion of the urban population is expected to increase to $70 \%$ worldwide. Despite fast rates of change and potential value for mitigation of carbon dioxide emissions, the organic carbon storage in human settlements has not been well quantified. Here, we show that human settlements can store as much carbon per unit area (23-42 $\mathrm{kg} \mathrm{C} \mathrm{m}^{-2}$ urban areas and $7-16 \mathrm{~kg} \mathrm{C} \mathrm{m}^{-2}$ exurban areas) as tropical forests, which have the highest carbon density of natural ecosystems $\left(4-25 \mathrm{~kg} \mathrm{C} \mathrm{m}^{-2}\right)$. By the year 2000 carbon storage attributed to human settlements of the conterminous United States was $18 \mathrm{Pg}$ of carbon or $10 \%$ of its total land carbon storage. Sixty-four percent of this carbon was attributed to soil, $20 \%$ to vegetation, $11 \%$ to landfills, and $5 \%$ to buildings. To offset rising urban emissions of carbon, regional and national governments should consider how to protect or even to increase carbon storage of human-dominated landscapes. Rigorous studies addressing carbon budgets of human settlements and vulnerability of their carbon storage are needed.
\end{abstract}

Keywords: building, carbon storage, landfill, urban area

Received 9 January 2009; revised version received 15 May 2009 and accepted 18 May 2009

\section{Introduction}

Although urban areas occupy a small proportion of the landmass - around $2.4 \%$ globally (Potere \& Schneider, 2007) - they are home to more than half of the world's people (UN, 2008). The urban areas of the world are expected to absorb all the population growth expected over the next four decades while at the same time drawing in some of the rural population. By 2050 the proportion of the urban population is expected to increase to $70 \%$ worldwide (UN, 2008). Future urban areas will most likely be less densely populated than today. Increases in the wealth of households and enhanced personal mobility lead to less dense human settlements which occupy more land per capita (EEA, 2006). Human settlements are arrayed on a gradient of density, from most to least dense, from urban, suburban, exurban, and rural. In the conterminous United States, the fraction of land settled at urban and exurban

Correspondence: Galina Churkina, Leibniz-Centre for Agricultural Landscape Research, 15374 Müncheberg, Germany, tel. + 4933432 82 129, fax + 493343282 1992, e-mail: churkina@zalf.de (defined here to include suburban and exurban developments) densities increased from 3.6\% in 1950 to $18.5 \%$ in 2000 (Brown et al., 2005). During the same time period, population rose at a much slower rate than did the increase in settled land area. Historical trends in Europe are similar. Since the mid-1950s, European cities have expanded on average by $78 \%$, whereas the population has grown by only 33\% (EEA, 2006). Expansion of human settlements involves replacement of natural vegetation or agricultural fields by artificial surfaces such as buildings, parking lots, and roads or by turf grasslands, garden plants, and trees.

Expansion of human settlements and reductions in their density leads to a higher per capita use of energy (Newman \& Kenworthy, 1999) and to an increase in the anthropogenic release of carbon dioxide, which has arguably been attributed mostly to urban areas (Grubler, 1994; O'Meara, 1999). Can human settlements with decreasing density and with higher fractions of green space, including exurban settlements, also offset these carbon dioxide releases? Offset of carbon dioxide emissions can be achieved through additional storage and protection of carbon pools located in human settlements. 
Human settlements store carbon in natural pools such as vegetation and soil as well as in anthropogenic pools (Bramryd, 1980; Churkina, 2008). Anthropogenic carbon pools encompass buildings, printed materials, landfills, clothing, and living organisms. Although estimates of carbon storage exist for urban forests (Nowak \& Crane, 2002), soils (Pouyat et al., 2006), and urbanized river basins (Boyle \& Lavkulich, 1997) estimates of total carbon storage in human settlements of different densities are lacking at a continental scale.

Here we quantify total storage of organic carbon in human settlements of different densities in the conterminous United States in 2000. We distinguish between human settlements of different densities such as urban and exurban areas, because, in addition to dense urban areas, important land-use changes and considerable human settlements also occur beyond the traditional urban fringe (Theobald, 2001).

\section{Materials and methods}

\section{Area and population of human settlements}

Low-density residential development scattered outside of suburbs and cities is extensive and widespread throughout the developed world. These patterns are, however, not captured in the traditional data on urbanization, because traditional definitions of urbanization are based on areas of dense settlement only and on population statistics (US Bureau of Census, 1991; UN, 2008). Population data are tied to primary residence and thus underestimate development in rural areas, especially those significantly affected by seasonal and recreational use (Brown et al., 2005). The density of housing units is a more precise indicator of urban land use and development at various degrees of intensity (Theobald, 2005), because it accounts better for development in rural areas.

In this study, area of human settlements was defined using the density of housing units in census blockgroups (Brown et al., 2005). We defined urban land as having more than one housing unit per $4000 \mathrm{~m}^{2}$. Exurban land included suburban lands and was defined as having one housing unit per $4000-162000 \mathrm{~m}^{2}$. Urban areas was associated with high impervious proportion (31 $\pm 13 \%)$, while exurban land was associated with low impervious proportion $(8 \pm 2 \%)$. Our definition of urban areas based on housing density is different from the definition based on population density adopted by the US Census (US Bureau of Census, 1991). In the latter definition land is classified as urban if it has at least 386 persons per $\mathrm{km}^{2}$ (or 1000 persons per mile ${ }^{2}$ ). The area of census tracts with housing units at urban densities (i.e. our definition) was $95474 \mathrm{~km}^{2}$ in 2000 , whereas the
Census definition of urban areas and urban clusters (US Bureau of Census, 2002) produced an area of $239567 \mathrm{~km}^{2}$. Standard definitions of exurban areas do not exist, but previous attempts have been made to quantify them (Nelson, 1992; Berube et al., 2006). By Nelson's definition, which was applied at the county level and is based on population size and location relative to the central city, there was 2.434 million $\mathrm{km}^{2}$ in exurban counties in 1985, compared with 1.393 million $\mathrm{km}^{2}$ in 2000 as determined by our definition applied to the housing density measure at the blockgroup level. Classifying exurban areas at the county level necessarily includes undeveloped areas and is likely an overestimate, but in both cases our area estimates are more conservative than other existing estimates.

Population densities in urban and exurban areas were estimated from US counties that were classified as 90-100\% urban or exurban (Brown et al., 2005), respectively. Urban areas had on average 2150 people per $\mathrm{km}^{2}$ and exurban areas had 50 people per $\mathrm{km}^{2}$. Urban and exurban population of the United States was obtained as a product of population densities and land areas.

\section{Carbon pools}

We considered the five largest carbon pools of human settlements, including buildings, waste, people, vegetation, and soil. We focus only on the carbon storage from organic or renewable sources and not from fossil fuel sources such as plastics, paints, asphalt, etc., because we were not able to make robust country-wide estimates for the latter. Total carbon storage in the anthropogenic pools of the conterminous United States was calculated from per capita estimates of wood use in a private house or commercial building, of municipal and construction waste, as well as of carbon in people. These per capita estimates were then multiplied by urban and exurban population accordingly. To obtain countrywide estimates of carbon storage in vegetation and soil we multiply corresponding average carbon densities by their fractional area of urban and exurban land (Table 1).

Vegetation and soils. Although urban green spaces can have diverse growth forms and species of vegetation, in this study we assume that the area of a human settlement is divided into three dominant surface types such as grass, forest, and impervious surface (Table 1). Relative fractions of these surface types vary from city to city. In this study we calculate average fractions of grass, forest, and impervious surface for urban areas based on the dataset reported by Nowak et al. (1996) and its update for urban forest (Nowak et al., 
Table 1 Areas and carbon density of different surface types of urban and exurban areas

\begin{tabular}{|c|c|c|c|c|}
\hline \multirow[b]{2}{*}{ Surface type } & \multicolumn{2}{|c|}{ Average area covered $(\%)$} & \multicolumn{2}{|l|}{ Carbon density $\left(\mathrm{gC} \mathrm{m}^{-2}\right)$} \\
\hline & $\begin{array}{l}\text { Urban } \\
\text { (Nowak et al., } \\
1996,2001 \text { ) }\end{array}$ & $\begin{array}{l}\text { Exurban } \\
\text { (Zhao et al., } \\
2007 \text { ) }\end{array}$ & $\begin{array}{l}\text { Aboveground } \\
\text { (vegetation) }\end{array}$ & Soil \\
\hline Impervious & $31 \pm 13$ & $8 \pm 2$ & Building/pavement & 3300 (Pouyat et al., 2006) \\
\hline Grass & $42 \pm 20$ & $66 \pm 1$ & 50 & 3500-14 000 (Kaye et al., 2005; Pouyat et al., 2006) \\
\hline Forest & $27 \pm 12$ & $26 \pm 1$ & $\begin{array}{l}8550 \pm 2600 \\
(\text { Nowak \& Crane 2002) }\end{array}$ & $\begin{array}{l}7100-8700 \\
\text { (Pouyat et al., 2006) }\end{array}$ \\
\hline
\end{tabular}

Mean value and standard deviation of percent area covered by impervious surface, grass, and forest are reported. Maximum and minimum carbon densities, if available, are given for vegetation and soil.

2001). Out of the original data, consisting of 58 cities worldwide, we choose only those US cities, where both forest and total green surface were reported. For the derived subset of 48 cities (Nowak et al., 1996), we calculate that one-third of the urban areas of the United States is impervious, e.g. paved or covered by buildings. The other two-thirds are green surfaces, e.g. covered by grasses or urban forests. In the first report (1996) urban forests cover $19 \pm 12 \%$ and nonforest green areas, such as grasses, cover $46 \pm 20 \%$ of urban area. Based on detailed analysis of remotely sensed data and forest field measurements, Nowak et al. (2001) reported higher fraction of forest in urban areas, which was $27 \%$ on average. We used the latest estimate of forest fraction in our study (Table 1) and ratio of urban/forest/grassland fractions from dataset reported by Nowak et al. (1996). It was more difficult to estimate average fractions of impervious surfaces, forest, and grasses for exurban areas, because there was no relevant systematic study done nationwide. Exurban land comprises land parcels or lots that are larger than those in urban areas, but which are generally too small to be considered for productive agricultural land use (Theobald, 2005). Following a recent study for Michigan (Zhao et al., 2007), we assume that more than $85 \%$ of exurban surface areas are covered by green vegetation and only $5-9 \%$ is impervious (Table 1). Our estimates of the area of impervious surfaces in $2000141000 \pm 40000 \mathrm{~km}^{2}$ were comparable to the respective estimates from remote sensing data $113000 \pm 13000 \mathrm{~km}^{2}$ (Elvidge et al., 2004).

We estimated carbon storage in vegetation $\left(C_{\text {veg }}\right)$ as a sum of carbon stored in grasslands and forest:

$$
C_{\mathrm{veg}}=\text { Area }_{\text {grass }} \times C_{\mathrm{vgrass}}+\text { Area }_{\mathrm{forest}} \times C_{\mathrm{vforest}}
$$

where $A r e a_{\text {grass/forest }}$ is the area occupied by grass or forest in urban or exurban areas; $C_{\text {vgrass/vforest }}$ is the carbon density of grass or forest in urban or exurban areas.
Soils in human settlements can be covered by impervious surfaces such as roads and buildings or by vegetation such as grasses and trees. We estimated storage of carbon in soils $\left(C_{\text {soil }}\right)$ as a sum of carbon stored in soils of urban or exurban forests, grasses, and under impervious surfaces:

$$
\begin{aligned}
C_{\text {soil }}= & \text { Area }_{\text {imp }} \times C_{\text {simp }}+\text { Area }_{\text {grass }} \times C_{\text {sgrass }}+\text { Area }_{\text {forest }} \\
& \times C_{\text {sforest }}
\end{aligned}
$$

where $A r e a_{\text {imp }}$ is the area covered by impervious surfaces in urban or exurban areas; $C_{\text {simp/sgrass/sforest }}$ is the carbon density of soil beneath impervious surfaces or grass or forest in urban or exurban areas.

We estimated maximum and minimum carbon storages in each surface type based in maximum and minimum values of carbon density where available and average values for area covered (Table 1). We calculated average storage of carbon in the US urban forests (whole tree) from dataset including 10 US cities (Nowak \& Crane, 2002), excluding data for Sacramento, which had high error in estimates. The carbon density of urban forests from this dataset was $8550 \pm 2600 \mathrm{gC} \mathrm{m}^{-2}$ (Table 1).

Buildings. Large amounts of carbon are accumulated in buildings, furniture, printed materials, and other manmade objects. We included structures and furniture in our calculations as the two largest components of a building and assumed carbon presently stored in other pools such as appliances, clothing, footware, etc. as negligible. Here we distinguish between private houses and commercial buildings including offices, hotels, schools, etc. We estimate organic carbon stored in different buildings as well as in furniture and books on per capita basis as

$$
\begin{aligned}
C_{\text {build }}= & \text { Num }_{\text {people }} \times\left(\text { Area }_{\text {house_capita }} \times C_{\text {unitarea_house }}\right. \\
& \left.+ \text { Area }_{\text {office_capita }} \times C_{\text {unitarea_office }}\right) \\
C_{\text {furn }}= & \text { Num }_{\text {people }} \times \text { weight }_{\text {furn }} \times f 1
\end{aligned}
$$




$$
\begin{aligned}
& C_{\text {unitarea_house }}=\text { weight }_{\text {unitarea }} \times f 1 \\
& C_{\text {unitarea_office }}=\text { weight }_{\text {unitarea }} \times f 1 \times f r a c_{\text {_ccom }}
\end{aligned}
$$

where $C_{\text {build }}$ and $C_{\text {furn }}$ is the carbon stored in buildings

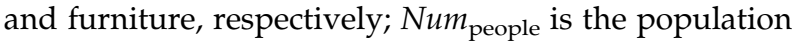
of urban or exurban areas; Area $a_{\text {house_capita/office_capita }}$ is the average area of house floor (US Bureau of Census, 2008) or commercial building (Energy Information Administration, 2003) area per capita; $C_{\text {unitarea_house/ }}$ unitarea_office is the carbon density of a private house or a commercial building per unit of floor area; Weight furn is the weight of dry organic matter in furniture and books per capita (300 kg, after (Bramryd, 1980); Weight $_{\text {unitarea }}$ is the wood weight per unit of house floor area (Wilson \& Boehland, 2005); frac_com is the fraction of wood in commercial building relative to private house $(0.1-0.25, \quad$ S. Chubbs, unpublished results), $f 1$ is the fraction of carbon in dry organic matter (0.5).

Wood use per house $\left(\right.$ Weight $\left._{\text {unitarea }}\right)$ in late 1990s varied from $40 \mathrm{~kg} \mathrm{~m}^{-2}$ (Wilson, 2006) in the south to $52-130 \mathrm{~kg} \mathrm{~m}^{-2}$ (Keoleian et al., 2000; Meil et al., 2007) in the north of the United States. These estimates include only lumber, oriented strand board, and plywood as the three most abundant construction materials of the total house mass (Keoleian et al., 2000). We used Weight $t_{\text {unitarea }}=40$, frac_com $=0.1$ and Weight $t_{\text {unitarea }}=130 \mathrm{~kg} \mathrm{~m}^{-2}$, frac_com $=0.25$ to estimate minimum and maximum carbon storage in buildings, respectively. The average estimate of carbon storage in buildings was based on an average of the abovementioned minimum and maximum values.

Waste. Our estimate of carbon storage in landfills included waste from households, construction, and demolition of buildings, as well as sludge from water treatment plants deposited at landfills. Because estimates of waste generation per capita were available only after 1950, we assumed in our calculations that the landfills in 2000 accumulated waste for 50 years. We estimated the amount of biomass-derived carbon which is not degradable and which accumulates in a landfill over the years. The biomass-derived carbon includes food waste, yard waste, papers, wood from demolition of buildings, and sludge. Total organic carbon accumulated in the landfills in 2000 was calculated as

$$
\begin{aligned}
& C_{\text {waste }}=\sum_{\mathrm{yr}=1950}^{2000} \mathrm{Num}_{\text {people }}^{y r} \times\left[\left(W_{\text {Mun }}^{\mathrm{yr}}+W_{\mathrm{C} \& \mathrm{D}} \times \mathrm{FL} \times \mathrm{FW}\right)\right. \\
&\left.\times \mathrm{CSF}+\mathrm{C}_{\mathrm{Sew}}^{\mathrm{yr}}\right]
\end{aligned}
$$

where CSF is a carbon sequestration fraction of solid waste [0.26-0.35, after (Barlaz, 1998)] without glass and metal; $W_{\text {Mun }}$ is the municipal solid waste deposited to landfills per capita per year (EPA, 2006a); $W_{C \& D}$ is the construction and demolition debris $(\mathrm{C} \& \mathrm{D})$ generated per capita in 1990s (Franklin Associates, 1998); FL is the fraction of construction and demolition debris deposited to landfills [0.6-0.8, (Franklin Associates, 1998)]; FW is the fraction of wood in construction and demolition waste [0.3, (Sandler, 2003)]; $C_{\text {Sew }}$ is the carbon in sewage per capita per year (Bramryd, 1980) deposited to landfills.

Around $60-80 \%$ of produced construction and demolition debris is deposited into landfills, while the rest is recycled or burned (Franklin Associates, 1998). We used $W_{C \& D}=0.6, C S F=0.26$, and $W_{C \& D}=0.8$, $\mathrm{CSF}=0.35$ to estimate minimum and maximum carbon accumulated in the landfills. The average estimate was calculated with 0.7 of construction and demolition waste deposited to landfills and CSF of 0.3.

People. In human settlements organic carbon is also stored in humans and pets. Previous estimates of average global carbon storage in humans and dogs showed that dogs store $<1 \%$ of the total carbon storage in humans (Bramryd, 1980). Therefore in this study we focused on the carbon storage only in the largest pool, which is human population $\left(C_{\text {hum }}\right)$ :

$$
C_{\text {hum }}=\text { Num }_{\text {people }} \times W e i g h t_{\text {capita }} \times f 1 \times f 2
$$

where Weight $t_{\text {capita }}$ is the average human body weight $(60 \mathrm{~kg}), \mathrm{f} 2$ is the fraction of dry matter in human body [0.3, (Bramryd, 1980)].

\section{Results and discussion}

\section{Carbon storage in anthropogenic pools and associated uncertainties}

Total storage of carbon in all anthropogenic components of urban and exurban areas was between 2.2 and $3.8 \mathrm{PgC}$, with an average estimate of $2.9 \mathrm{PgC}$ in 2000 . This estimate corresponds to the US total urban and exurban population which was 274850000 people in 2000. More than two-thirds of this carbon $(1.8-2.5 \mathrm{PgC}$, average estimate $-2.1 \mathrm{PgC}$ ) was stored in the landfills (Fig. 1). The rest $(0.4-1.3 \mathrm{PgC}$, average estimate $-0.8 \mathrm{PgC})$ was stored in buildings. Because we did not account for storage of carbon from fossil fuel sources such as asphalt, concrete, plastic, etc., we most likely underestimate total carbon storage.

Landfills can accumulate appreciable amounts of carbon over time, not only because of biologically recalcitrant materials such as plastic, rubber, and leather, but also because some fraction of paper, wood, and food waste may decompose extremely slowly. The 

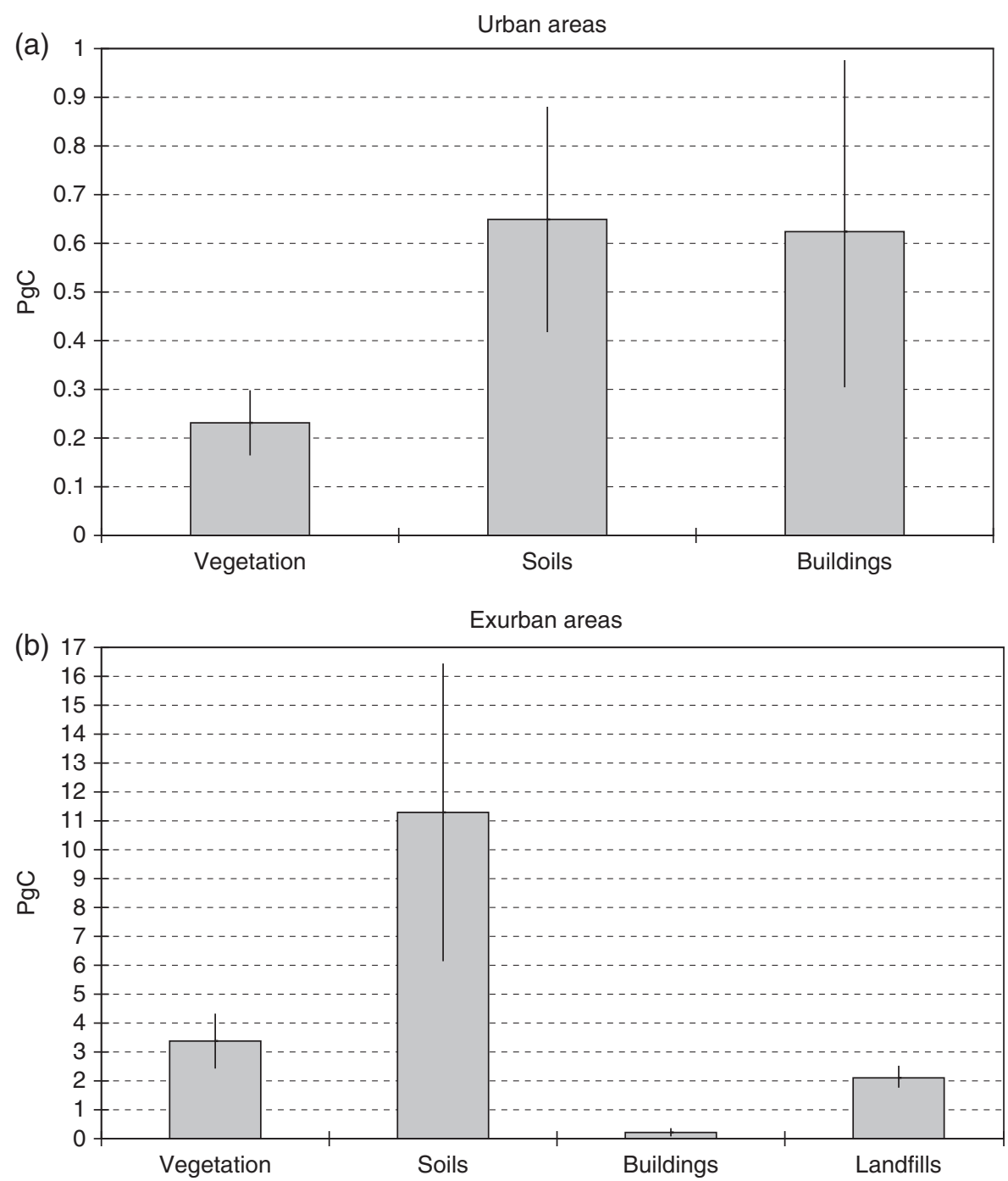

Fig. 1 Carbon storage in four major pools of urban (a) and exurban (b) areas in the conterminous United States in 2000. The top of each bar shows the average estimate. The vertical lines show the uncertainty range for each pool's estimate.

reason for this is that lignin, which decomposes very slowly and prevents some organic material from decaying, is always a part of the composition of waste. The amount of carbon stored in a landfill depends on the landfill's age and the composition of waste deposited there over time. Since estimates of waste generation per capita are available only after 1950, we assumed in our calculations that the landfills were not older than 50 years (see 'Materials and methods'). Therefore our carbon storage estimate for landfills may be low. The uncertainty from the composition of waste (Barlaz, 1998) contributed around $23 \%$ to the uncertainty of our estimate of carbon storage in landfills in 2000 (Fig. 1b).

Organic carbon is also stored in buildings in substantial amounts. This carbon is incorporated in the build- ing's structure (including framing, flooring, roofing, and walls), furniture, books, and other organic materials. According to our estimates $87-91 \%$ of total carbon in buildings was stored in the structure of private houses, 3-7\% - in commercial buildings, and 3-10\% in furniture. The amount of carbon per unit of floor area depends on the purpose of a building (e.g. private houses have more carbon than commercial buildings) and on the building's location [e.g. the general trend is that the houses in the north have more wood per floor area than in the south (Wilson, 2006)]. The wood use per unit of floor area of a house is highly variable. In the conterminous United States it varies by a factor of three (Keoleian et al., 2000; Wilson, 2006; Meil et al., 2007) and mostly explains the large range of carbon storage values presented in this study (Fig. 1). 
Carbon storage in natural pools and associated uncertainties

Carbon storage in vegetation and soils within human settlements is estimated between 11 and $26 \mathrm{PgC}$ with the average estimate of $18.5 \mathrm{PgC}$ in 2000 (Table 2). This corresponds to 1.5 million $\mathrm{km}^{2}$ of land at urban and exurban housing densities. Soils stored most of this carbon or $7-17 \mathrm{PgC}$, with the average estimate of $12 \mathrm{PgC}$. Vegetation, mostly woody, stored between 3 and $5 \mathrm{PgC}$, with the average estimate of $4 \mathrm{PgC}$.

This range of values incorporates the uncertainty in the carbon density of vegetation and soils. The average carbon storage in soils and vegetation in human settlements of the United States was estimated to be $0.9 \mathrm{PgC}$ for urban $\left(95018 \mathrm{~km}^{-2}\right)$ and $14 \mathrm{PgC}$ for exurban areas $\left(1395347 \mathrm{~km}^{2}\right)$ in 2000 . This is on average $\sim 10 \mathrm{~kg} \mathrm{C} \mathrm{m}^{-2}$ in vegetation and soils of human settlements of both densities. This estimate compares well with the recent estimate of $9 \mathrm{kgC} \mathrm{m}^{-2}$ reported by Pouyat et al. (2006), who estimated in total $2.6 \mathrm{PgC}$ in vegetation and soils over $280332 \mathrm{~km}^{2}$ of urban area of the United States. The latter estimate is based on a different definition of urban area and more sub-categories in urban vegetation and soils for different states.

\section{Total carbon storage in human settlements}

Total carbon storage in the United States urban and exurban areas was $18.5 \mathrm{Pg}$ in 2000 (Table 2), that is $10 \%$ of the carbon stored in all land ecosystems of the United States (King et al., 2007). Based on this estimate, human settlements store more carbon than the US croplands, which store $14 \pm 7 \mathrm{PgC}$ (King et al., 2007) on the area of

Table 2 Carbon storage in major pools of human settlements of the conterminous United States in 2000 and its comparison to the total carbon stocks in the US ecosystems (King et al., 2007)

\begin{tabular}{lclc}
\hline & $\begin{array}{l}\text { Average } \\
\text { estimate } \\
(\mathrm{PgC})\end{array}$ & $\begin{array}{l}\text { Low } \\
\text { estimate } \\
(\mathrm{PgC})\end{array}$ & $\begin{array}{l}\text { High } \\
\text { estimate } \\
(\mathrm{PgC})\end{array}$ \\
\hline Soils & 11.9 & 6.6 & 17.3 \\
Vegetation & 3.6 & 2.6 & 4.6 \\
Landfills & 2.1 & 1.8 & 2.5 \\
Buildings & 0.9 & 0.4 & 1.3 \\
$\begin{array}{l}\text { Humans } \\
\text { Human settlements }\end{array} \quad 18.5$ & 11.4 & - \\
$\quad$ total) & 0.0024 & - & 25.7 \\
All US land & 178 & 89 & 267 \\
$\quad$ ecosystems & & & \\
\hline
\end{tabular}

Calculations of average, low, and high estimates are reported for carbon storage.
$1718531 \mathrm{~km}^{2}$ (Brown et al., 2005). The accuracy of our estimates $\sim 40 \%$ is comparable to the uncertainty in the estimates for the US ecosystems $50 \%$ by (King et al., 2007). Uncertainties in both estimates are relatively high and reducing them is not easy given the inherent uncertainty from land use classification and carbon density of heterogeneous American landscapes.

Human settlements have more diverse pools than natural ecosystems to store carbon over the long-term. In settlements, organic carbon is stored not only in vegetation and soils, but also in buildings, furniture, printed materials, landfills, and people. Our results suggest that four carbon pools predominate (Table 2): soils $(7-17 \mathrm{PgC})$, vegetation $(3-5 \mathrm{PgC})$, landfills (1.8-2.5 Pg C), and buildings $(0.4-1.3 \mathrm{PgC})$. Storage of carbon in humans $(0.0024 \mathrm{PgC})$ is drastically lower. Soil is by far the largest carbon pool taking $64 \%$ of the total carbon storage in all human settlements (Fig. 2). In the more dense urban areas, however, the buildings and soils store approximately the same amount of carbon or $\sim 41 \%$ and $44 \%$, respectively, while the vegetation carbon pool is smaller $\sim 15 \%$. In exurban areas carbon storage in soils dominates $(\sim 67 \%)$, while storage in vegetation and landfills is considerably smaller or $\sim 20 \%$ and $\sim 12 \%$, respectively. Carbon storage in buildings in exurban areas is $\sim 1 \%$.

The range of carbon density of human settlements are comparable with or even higher than the carbon density of a tropical rain forest, which has the highest carbon density among natural ecosystems of $4-25 \mathrm{~kg} \mathrm{C} \mathrm{m}^{-2}$ (Olson et al., 1983). We estimate that the carbon density of urban areas ranges between 23 and $42 \mathrm{~kg} \mathrm{C} \mathrm{m}^{-2}$. In

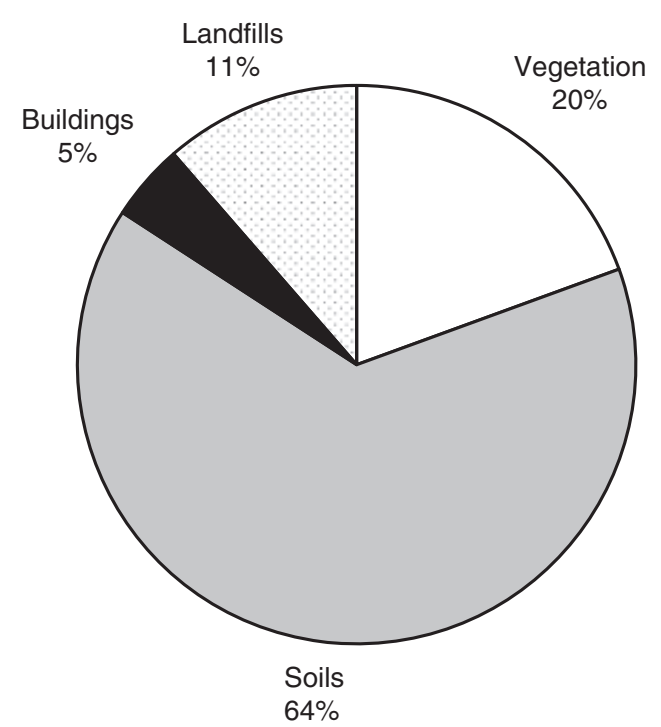

Fig. 2 Contributions of four major pools to the total carbon storage in urban and exurban areas of the conterminous United States. 
exurban areas the range of carbon density is between 7 and $16 \mathrm{~kg} \mathrm{C} \mathrm{m}^{-2}$. The carbon density of human settlements is high, because they have more pools than natural ecosystems to store carbon. In addition to vegetation and soil, human settlements store carbon also in human-made pools such as buildings and landfills. The carbon density of anthropogenic pools is high $\left(17-29 \mathrm{~kg} \mathrm{C} \mathrm{m}^{-2)}\right)$ in urban and low $\left(0.7-0.4 \mathrm{~kg} \mathrm{C} \mathrm{m}^{-2}\right)$ in exurban areas. The carbon density of natural pools is comparable in urban $\left(6-12 \mathrm{~kg} \mathrm{C} \mathrm{m}^{-2}\right)$ and exurban $\left(6-15 \mathrm{~kg} \mathrm{C} \mathrm{m}^{-2}\right)$ areas.

\section{Effect of urbanization on the land carbon storage}

In the future, more terrestrial carbon storage will be contained in human settlements, simply because urban and exurban areas are expanding very quickly (Brown et al., 2005; EEA, 2006). In absolute numbers, the carbon storage attributed to the soils and vegetation of human settlements increased by $500 \%$ in 50 years, or from $\sim 3 \mathrm{PgC}$ in 1950 to $\sim 18 \mathrm{PgC}$ in 2000. The 1950 estimate was calculated using the same methodology as for 2000, but with population and area of human settlements for 1950 as reported in Brown et al. (2005). We accounted for changes in waste generation as well as commercial and house floor area per capita between 1950 and 2000. However these per capita changes between 1950 and 2000 were small in comparison with expansion of human settlements. Therefore the increase in carbon storage between 1950 and 2000 was mostly related to the expansion of urban and exurban lands at a higher rate than population growth. Between 1950 and 2000 the area of urban and exurban lands increased by $400 \%$, while urban population increased only by $100 \%$ (Fig. 3).

Carbon pools of human settlements are likely to be in a transient state, with the exception of soils sealed by impervious surfaces. The natural pools of carbon are changing, because urban vegetation is managed. Depending on climate, pollution, and intensity of management the vegetation and soil may accumulate as well as loose carbon. The anthropogenic pools are unlikely to be in a steady state, because in- and outflow of carbon in these pools as well as carbon density is influenced by lifestyles and wealth of people as well as policies, which are always in transition. For instance, fraction of municipal solid waste deposited to landfills has decreased from $94 \%$ in 1960 to 57\% in 2000, although household waste generation per capita has been increasing by $\sim 2 \%$ per year between 1960 and 2000 (EPA, 2006a). More waste has been combusted or recycled over the years. As a result, waste deposition to landfills in 2000 was almost equal to 1960. The residence time of carbon entering the landfills has likely changed, because of

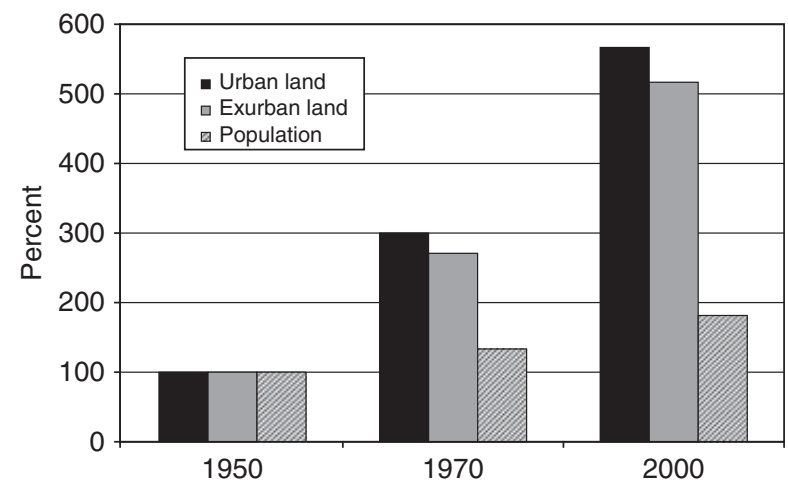

Fig. 3 Changes in population and land affected by human settlements after Brown et al. (2005). Urban land has one housing unit per $4000 \mathrm{~m}^{2}$. Exurban land has one housing unit per 4000-162000 $\mathrm{m}^{2}$.

higher fraction of recalcitrant materials as well as shielded organic materials in the waste composition.

Conversion of agricultural or other land to urban and exurban uses may increase its carbon uptake and carbon storage. Low-density exurban development, characterized by a large proportion of vegetation, can be more productive in the form of gross photosynthetic uptake than the agricultural land it replaces (Zhao et al., 2007). Several studies (Kaye et al., 2005; Golubiewski, 2006) point out that soils in urban parks and lawns can store large amounts of carbon, which could more than double the amount stored in native grasslands or agricultural fields. Also an increase in tree cover on land converted into urban and exurban uses would contribute to higher rates of carbon uptake and storage.

Different strategies for carbon storage in human settlements should be considered in line with the estimates of associated greenhouse gas emissions. Maintenance of urban vegetation and soil is associated with higher carbon emissions than of natural ones due to use of fuel-driven machinery, such as lawnmowers and petroleum-based fertilizers. Suburbanization leads to longer daily travel distances and therefore to higher carbon emissions from road transportation. A recent review (Brown et al., 2008) attributes increase in the US carbon emissions from road transportation to suburbanization along with increasing personal wealth. Between 1970 and 2005 the average vehicle miles traveled per American household per year has almost doubled (Bureau of Transportation Statistics, 2007). Use of wood in buildings, instead of brick, aluminum, steel, and concrete, can increase carbon storage in human settlements and reduce emissions of greenhouse gases related to construction (Buchanan \& Levine, 1999) and life cycle of buildings (Upton et al., 2008). The emissions of greenhouse gases are reduced because, in contrast, to fabrica- 
tion of wooden construction materials, production of bricks, and concrete is much more energy intensive and accompanied by high $\mathrm{CO}_{2}$ emissions from burning of fossil fuel. Any increase in wood use would have implications for the wood production. Rising demand for wood must be accompanied by increases in areas of forest being managed for long-term sustainable timber production. Comprehensive life-cycle assessments are required to assess the potential for future strategies to reduce carbon emissions and to increase carbon storage in human settlements. Dynamic stock and flow models should be constructed to develop a more accurate analysis of carbon storage in the building and landfill reservoirs. More refined models are necessary to account for material residence time which is influenced by renovation activities and building service life, and the fate of waste materials in landfill reservoirs which also requires modeling of greenhouse gas emissions from landfill decomposition processes (EPA, 2006b).

Although human settlements are unlikely to become net sinks of carbon, they can harbor appreciable carbon pools. Given the large area covered by human settlements of various densities, we have an opportunity to consider how to store more carbon per unit of emitted carbon in the places we live. Rigorous studies addressing carbon budgets of human settlements and vulnerability of their carbon storage are needed.

\section{Outlook}

There is a growing dataset of carbon gains and losses in vegetation and soils following urbanization, and a number of methods of validating urban carbon balance modeling, including top down atmospheric monitoring and urban 'metabolic' studies of whole ecosystem mass and energy flow (Pataki et al., 2006). What is still missing is a framework targeted toward consolidation of ground and remote measurements of different aspect of urbanization at continental scale. Estimates presented in our study have large uncertainty, because they are based on the values compiled from literature review. This uncertainty can be reduced by research conducted in a consistent framework. Consistent estimates of forest, grassland, and impervious fractions of urban and exurban areas would be the first step in this direction. Until now these fractions have been estimated separately and with different techniques. Accurate nation wide survey of organic and inorganic carbon densities of residential and office buildings would also be helpful. Wood content has been estimated in residential buildings, but not in the office buildings of the United States. Even less is known about inorganic carbon storage and its distribution in human settlements.

\section{Acknowledgements}

Most of the analysis presented in this study was performed while G. Churkina was on sabbatical at the School of Natural Resources and Environment, the University of Michigan. Financial support for this stay was kindly provided by the German Research Foundation (GZ: CH413/2-1). D. Brown acknowledges financial support from the National Science Foundation Program on the Dynamics of Coupled Natural and Human Systems (GEO0814542). We are grateful to Detlef Sprinz and William Curie for very helpful comments and suggestions to the manuscript.

\section{References}

Barlaz MA (1998) Carbon storage during biodegradation of municipal solid waste components in laboratory-scale landfills. Global Biogeochemical Cycles, 12, 373-380.

Berube A, Singer A, Wilson JH, Frey WH (2006) Finding Exurbia: America's Fast-Growing Communitites at the Metropolitan Fringe. Brookings Institution, Metropolitan Policy Program, Washington, DC.

Boyle CA, Lavkulich L (1997) Carbon pool dynamics in the lower fraser basin from 1827 to 1990. Environmental Management, 21, 443-455.

Bramryd T (1980) Fluxes and accumulation of organic carbon in urban ecosystems on a global scale. In: Urban Ecology (eds Bornkamm R, Lee JA, Seaward MRD), pp. 3-12. Blackwell Scientific Publications, Oxford.

Brown DG, Johnson KM, Loveland TR, Theobald DM (2005) Rural land-use trends in the conterminous United States. Ecological Applications, 15, 1851-1863.

Brown MA, Southworth F, Sarzynski A (2008) Shrinking the carbon footprint of metropolitan America. The Brookings Institution, Washington.

Buchanan AH, Levine SB (1999) Wood-based building materials and atmospheric carbon emissions. Environmental Science and Policy, 2, 427-437.

Bureau of Transportation Statistics (2007) National Transportation Statistics 2007, U.S. Department of Transportation, Research and Innovative Technology Administration, Bureau of Transportation Statistics, National Transportation Statistics. Available at http://www.bts.gov/publications/national_ transportation_statistics/

Churkina G (2008) Modeling the carbon cycle of urban systems. Ecological Modelling, 216, 107-113.

EEA (2006) Urban sprawl - the ignored challenge. European Environment Agency (EEA), Copenhagen, Denmark.

Elvidge C, Milesi C, Dietz JB, Tuttle BT, Sutton PC, Nemani RR, Vogelmann JE (2004) U.S. constructed area approaches the size of Ohio. Eos, 85, 233-240.

Energy Information Administration (2003) Commercial buildings energy consumption survey. Available at http://www.eia.doe.gov/ emeu/cbecs/ (accessed 1 April 2009).

EPA (2006a) Municipal solid waste in the United States: 2005 facts and figures, The U. S. Environmental Protection Agency. Avail able at http://www.epa.gov/msw/msw99.htm (accessed 1 April 2009).

EPA (2006b) Solid waste management and greenhouse gases. A life cycle assessment of emissions and sinks, The U.S. Environmental 
Protection Agency, 140 pp. Available at http://epa.gov/ climatechange/wycd/waste/SWMGHGreport.html

Franklin Associates (1998) Characterization of building-related construction and demolition debris in the United States. The U.S. Environmental Protection Agency (EPA). Available at http:// www.epa.gov/osw/hazard/generation/sqg/c\&d-rpt.pdf

Golubiewski NE (2006) Urbanization increases grassland carbon pools: effects of landscaping in Colorado's front range. Ecological Applications, 16, 555-571.

Grubler A (1994) Technology. In: Changes in Land Use and Land Cover: a Global Perspective (eds William BM, Turner II BL), pp. 287-328. Cambridge University Press, Cambridge, UK.

Kaye JP, McCulley RL, Burke IC (2005) Carbon fluxes, nitrogen cycling, and soil microbial communities in adjacent urban, native and agricultural ecosystems. Global Change Biology, 11, 575-587.

Keoleian GA, Blanchard S, Reppe P (2000) Life-cycle energy, costs, and strategies for improving a single-family house. Journal of Industrial Ecology, 4, 135-156.

King AW, Dilling L, Zimmerman GP et al. (eds) (2007) The First State of the Carbon Cycle Report (SOCCR): The North American Carbon Budget and Implications for the Global Carbon Cycle, 242pp. US Climate Change Science Program, Washington, DC.

Meil J, Wilson J, O'Connor J, Dangerfield J (2007) An assessment of wood product processing technology advancement between the CORRIM I and II studies. Forest Products Journal, 57, 83-89.

Nelson AC (1992) Characterizing exurbia. Journal of Planning Literature, 6, 350-368.

Newman PWG, Kenworthy J (1999) Sustainability and Cities: Overcoming Automobile Dependence. Island Press, New York.

Nowak DJ, Crane DE (2002) Carbon storage and sequestration by urban trees in the USA. Environmental Pollution, 116, 381-389.

Nowak DJ, Noble MH, Sisinni SM, Dwyer JF (2001) People and trees assessing the US urban forest resource. Journal of Forestry, 99, 37-42.

Nowak DJ, Rowntree RA, McPherson EG, Sisinni SM, Kerkmann ER, Stevens JC (1996) Measuring and analyzing urban tree cover. Landscape and Urban Planning, 36, 49-57.

Olson JS, Watts JA, Allison LJ (1983) Carbon in live vegetation of major world ecosystems. Oak Ridge National Laboratory, Oak Ridge, TN, USA.

O'Meara M (1999) Reinventing Cities for People and the Planet. Worldwatch, Washington.
Pataki DE, Alig RJ, Fung AS et al. (2006) Urban ecosystems and the North American carbon cycle. Global Change Biology, 12, 2092-2102.

Potere D, Schneider A (2007) A critical look at representations of urban areas in global maps. GeoJournal, 69, 55-80.

Pouyat RV, Yesilonis ID, Nowak DJ (2006) Carbon storage by urban soils in the United States. Journal of Environmental Quality, 35, 1566-1575.

Sandler K (2003) Analyzing what's recyclable in C\&D debries. BioCycle, 44, 51-54.

Theobald DM (2001) Land-use dynamics beyond the American urban fringe. Geographical Review, 91, 544-564.

Theobald D (2005) Landscape patterns of exurban growth in the USA from 1980 to 2020. Ecology and Society, 10, 32. Available at http://www.ecology and society.org/vol10/1ss1/art32/

UN (2008) World Urbanization Prospects: the 2007 Revision. United Nations, New York. Available at http://www.un.org/esa/ population/publications/wup2007/2007WUP_Highlights_ web.pdf

Upton B, Miner R, Spinney M, Heath LS (2008) The greenhouse gas and energy impacts of using wood instead of alternatives in residential construction in the United States. Biomass and Bioenergy, 32, 1-10.

US Bureau of Census (1991) 1990 Census of Population and Housing. US Bureau of Census, Washington, DC, USA.

US Bureau of Census (2002) Census 2000 Urban and Rural Classification US Census, Geography Division. US Bureau of Census. Available at http://www.census.gov/geo/www/ua/ua 2k.html (accessed 15 May 2009).

US Bureau of Census (2008) American Housing Survey. Housing and Household Economic Statistics Division, US Bureau of Census. Available at http://www.census.gov/hhes/www/ housing/ahs/ahs.html

Wilson A, Boehland J (2005) Small is beautiful: U.S. house size, resource use, and the environment. Journal of Industrial Ecology, 9, 277-287.

Wilson JB (2006) Using wood products to reduce global warming. In: Forests, Carbon and Climate Change (eds Achteman G, Bachelet D, Burnett M, Cathcart J, Delaney M, Raymond JD, Harmon M, Kline JD, Krankina ON, Lenihan JM, Millat C, Nielson RP, Salwasser H, Taylor G, von Hagen B, Wilson J), pp. 117-129. Oregon Forest Resources Institute, Portland.

Zhao T, Brown DG, Bergen KM (2007) Increasing gross primary production (GPP) in the urbanizing landscapes of Southeastern Michigan. Photogrammetric Engineering and Remote Sensing, 73, 1159-1168. 